\title{
POLA PERKAWINAN, POLA KONSUMSI DAN STATUS GIZI BALITA ORANG RIMBA DI DESA SUNGAI TERAP DAN HAJRAN
}

\section{Marriage Patterns, Consumption Patterns and Nutritional Status of Orang Rimba in Sungai Terap and Hajran Villages}

\author{
Ummi Kalsum $^{1}$, Raden Halim ${ }^{1}$, Adelina Fitri ${ }^{1}$ \\ ${ }^{1}$ Program Studi Kesehatan Masyarakat Fakultas Kesehatan Masyarakat Universitas Jambi
}

\begin{abstract}
Abstrak
Salah satu suku minoritas di Jambi yang hidup nomaden dan marginal adalah Orang Rimba. Hutan yang menjadi sumber penghidupan yang saat ini jauh berkurang membuat Orang Rimba semakin tak berdaya dan berakibat pada kematian karena kekurangan gizi, serta penyakit infeksi. Penelitian bertujuan untuk mengetahui gambaran pola perkawinan, pola konsumsi dan status gizi balita Orang Rimba dengan menggunakan disain penelitian kualitatif. Penelitian dilaksanakan dari bulan April sampai Oktober 2018. Hasil dari penelitian ini didapatkan sebesar 21,7\% balita pendek dan 24\% balita gizi kurang. Pola perkawinan kebanyakan dilakukan diantara keluarga atau memiliki hubungan kekerabatan. Pola konsumsi tinggi lemak, rendah sayur dan buah serta asupan energi bersumber dari ubi dan beras. Peningkatan aksesibilitas terhadap layanan kesehatan utamanya upaya promotif dan preventif dapat diberikan secara lebih paripurna dan berkelanjutan pada Orang Rimba.
\end{abstract}

Kata Kunci : Perkawinan, Pola Konsumsi, Status Gizi, Balita, SAD, Orang Rimba

\begin{abstract}
Ethnic minority in Jambi who lives nomadically and marginally is Orang Rimba. Forests that are now much reduced source of livelihood made Orang Rimba increasingly helpless and result in deaths due to malnutrition and infectious diseases. The study aimed to determine the description of marriage patterns, consumption patterns and nutritional status of Orang Rimba children using qualitative research designs. The study was conducted from April to October 2018. The results of this study were $21.7 \%$ of children underfive and $24 \%$ of children underfive were malnourished. The pattern of marriage was mostly done between families or having kinship relationships. High fat consumption patterns, low in vegetables and fruits and energy intake were sourced from sweet potatoes and rice. Increasing accessibility to health services, especially promotive and preventive efforts, can be provided more fully and sustainably for Orang Rimba.
\end{abstract}

Keywords : marriage, consumption, nutritional status, SAD, indigenous people

Korespondensi : Ummi Kalsum

Email : ummi2103@unja.ac.id 


\section{PENDAHULUAN}

Permasalahan gizi balita di Indonesia saat ini masih berkutat pada masalah gizi kurang seperti underweight, stunting dan wasting, meskipun permasalahan gizi lebih juga semakin meningkat. Pada tahun 2016, secara global sebesar 155 juta balita stunting, 52 juta wasting dan 41 juta kelebihan berat badan (overweight) ${ }^{1}$. Di Indonesia prevalensi balita underweight terlihat meningkat yaitu $17,9 \% \quad$ (2010) menjadi 19,6\% (2013). Prevalensi stunting juga mengalami peningkatan yaitu $35,6 \%$ tahun 2010 menjadi $37,2 \%$ pada tahun 2013. Prevalensi underweight dan stunting di Provinsi Jambi sendiri masih diatas prevalensi Indonesia yaitu $19,7 \%$ dan $37,9 \%^{2}$.

Di Provinsi Jambi, dikenal suku anak dalam atau orang Rimba yang merupakan suku terasing dan hidup termarginalkan. Orang rimba mempunyai konsep hidup nomaden dan marginal. Mereka hidup mengandalkan hutan sebagai sumber penghidupannya yang saat ini sudah jauh berkurang, sehingga membuat mereka semakin tak berdaya. Keterbelakangan dan kemiskinan menjadikan mereka rentan terhadap penyakit dan kematian. Banyak kematian akibat kekurangan gizi dan pangan serta penyakit infeksi. Kematian banyak terjadi pada anak-anak orang rimba karena kurang gizi.
Derajat kesehatan Orang Rimba di Provinsi Jambi tergolong rendah. Angka kesakitan dan kematian Orang Rimba sangat tinggi. Angka kematian banyak terjadi pada anak-anak. Karena hygiene personal, tingkat pendidikan dan pengetahuan yang rendah serta kehidupan mereka yang primitif, maka morbiditas penyakit pada orang Rimba masih berkisar pada penyakit infeksi seperti ISPA/Pneumonia, Diare, Kecacingan dan penyakit kulit. Penyakit-penyakit berbasis lingkungan menjadi pola keseharian yang umum terjadi pada orang rimba. Selain permasalahan kekurangan gizi dan stunting, ditemukan $33,9 \%$ orang Rimba menderita Hepatitis B, 24,26\% terkena Malaria (Laporan hasil penelitian Lembaga Eijkman bekerjasama dengan KKI Warsi, 2016).

Orang Rimba mempunyai kebudayaan tersendiri. Mereka merupakan suku yang cenderung defensif dan tidak terbiasa melakukan peperangan atau berjuang untuk mempertahankan haknya. Orang Rimba sangat tergantung dan hidup dari alam, dengan peralatan yang masih sangat sederhana. Orang Rimba biasa hidup dalam komunitas kecil, tertutup dan homogen yang sangat bertumpu pada hubungan kekerabatan (Dinas Sosial, 2013). Mereka juga melakukan perkawinan diantara komunitas kelompok mereka yang relatif adalah keluarga dan 
umumnya terjadi pada usia yang masih sangat muda.

Sebagaimana lazimnya proses perkawinan pada masyarakat Indonesia secara umum, perkawinan Orang Rimba juga didahului oleh pertemuan antara dua remaja yang berlainan jenis. Perlu diketahui bahwa umur ketika seorang jejaka menjadi pengantin (kawin) pada umumnya 11-14 tahun, sedangkan seorang gadis pada umumnya berumur 17-21 tahun. Saat ini, Undang-Undang Perkawinan di Indonesia menyatakan bahwa usia terendah untuk perkawinan yang sah bagi perempuan adalah 16 tahun dan laki-laki 19 tahun. Tetapi UndangUndang ini bertentangan dengan UU Perlindungan Anak 2002 (direvisi pada tahun 2014) yang menyatakan bahwa usia anak adalah dibawah 18 tahun dan orang tua bertanggung jawab untuk mencegah perkawinan usia anak ${ }^{3}$.

Kehidupan Orang Rimba yang masih primitif khususnya di Sungai Terap dan Hajran yang merupakan wilayah kerja Puskesmas Durian Luncuk tentunya berdampak pada pola perkawinan, dan pola konsumsi dimana berakibat langsung pada permasalahan gizi dan kesehatan ibu dan anak utamanya status gizi balitanya.

Tujuan Penelitian ini adalah untuk mengetahui gambaran dan mempelajari hubungan pola perkawinan dan pola konsumsi terhadap status gizi balita pada orang rimba di Desa Sungai Terap dan Desa Hajran Kabupaten Batanghari Jambi.

\section{METODE}

Penelitian ini adalah deskriptif, menggunakan pendekatan Mixed Method dengan pendekatan kualitatif sebagai pendekatan utama. Penelitian dilaksanakan di Kecamatan Bathin XXIV Kabupaten Batanghari Jambi yang berlokasi di Desa Sungai Terab dan Hajran. Populasi adalah Balita Orang Rimba yang tinggal dan bersedia berpartisipasi yang diwakili pleh Tumenggung (Jernang) dari kelompok SAD tersebut. Penelitian dilaksanakan selama kurang lebih 6 bulan (April hingga Oktober 2018). Pengumpulan data dilakukan selama kurang lebih dua bulan yaitu Agustus hingga September 2018.

Sampel penelitian adalah semua balita (12-60 bulan) pada kelompok orang Rimba di Desa Sungai Terap dan Desa Hajran. Jumlah Balita yang ditemui dan dapat diukur antropometrinya adalah 30 orang dari 109 Kepala Keluarga yang berhasil ditemui di dua Desa tersebut.

Pengumpulan data dilakukan menggunakan wawancara mendalam, observasi dan pengukuran antropometri. Metode kualitatif dilakukan untuk mengetahui secara mendalam terkait pola perkawinan pada orang Rimba menggunakan lima orang Informan yaitu 
Fasilitator WARSI, Tumenggung, Wakil Tumenggung, Menti dan Ibu balita. Lima informan ini dipilih berdasarkan prinsip kecukupan dan kesesuaian terhadap tujuan penelitian ini. Data dianalisis secara deskriptif dan Content Analysis.

\section{HASIL}

\section{Pola Perkawinan Suku Anak Dalam}

Pola Perkawinan dilihat dari tata cara dan tahapan pernikahan suku anak dalam di Kecamatan Bathin XXIV diuraikan oleh salah satu informan yang berasal dari Komunitas Konservasi WARSI Jambi dan juga beberapa informan lainnya. Berikut beberapa cuplikan dari hasil wawancara tersebut :

"Harus ado hakimnyo, terus rapat nentukan kapan nak negak balainyo. Abis itu barulah di nikahkan. yang lanang ngomong ke bapaknyo dulu, nak nikahi cewek itu terus bapak lanang nemui ke betinonyo yang nak di nikahi", (M, Sungai Terab 29 Juli 2018)

"Biasanyo anak mau menikah itu pada musim buah-buahan. Jadi anak-anak nak nikah itu negak pentas. Ado ketemu keluargo yang cewek samo cowoknyo" (T, Sungai Terab, 29 Juli 2018)

Pola perkawinan sedarah antar sesama keluarga masih terjadi di Suku Anak Dalam atau orang Rimba Jambi, meskipun ada peraturan yang melarang. Jika pernikahan sedarah masih juga terjadi maka ada sanksi atau denda yang berikan. Menurut informan denda tersebut cukup mahal bila dilakukan. Berikut ini adalah cplikna hasil wawancara terhadap beberapa orang informan :

"Dak biso, sebenarnyo dak boleh, memang ado kasusnyo kayak gitu, mereka tu keluar dari adat mereka. Sebetulnyo kek gini bu, sederhananyo contoh nyo kemaren tu Besilo dio tu adek beradek dengan Induk Mendari istri Wakil. Wakil ini nikah samo adek Besilo, Besilo ini nikah samo anak Wakil. Kalo adao yang melakukan dengan denda yang sangat tinggi, 500 keping kain." (DK, Jambi, 3 Agustus 2018)

"Itu ado, banyak aturannyo. Di kami tu di sebut sumbang jadi dak boleh nikah samo keluargo. Sumbang tu ado paman, bapak, emak samo anak buah itu dak boleh di nikahin : itu walaupun seandainyo terjadi ado hukumannyo hukum mati. Kalau nikah samo bini kanti itu jugo di hukum mati. Kecuali ponakan jauh hukumannyo besak itu 500 lembar kain." (M, Sungai Terab 29 Juli 2018)

"Nah itu ado di larang ado di bolehkan. Jadi kalo keluargonyo boleh yo tetap nikah kalau dak boleh yo dak jadi" (T, Sungai Terab, 29 Juli 2018) 
Poligami atau istri lebih dari satu juga terjadi pada Suku Anak Dalam, tidak ada peraturan tertulis yang membatasi jumlah istri yang boleh dinikahi. Memutuskan untuk menikah lagi pada laki-laki dewasa di Suku Anak Dalam biasanya atas izin dari istri pertama, jika tidak ada izin dari istri pertama maka si istri boleh meminta untuk berpisah atau suami membayar denda kepada istri tersebut, sebagaimana pada cuplikan hasil wawancara berikut ini

"Lazim, semua laki-laki boleh melakukan poligami, tidak harus tumenggung. Lebih ke perempuannya kalo itu bu, kalo perempuannya mau itu diperbolehkan. Awalnyo tu sebenarnyo tu dak mau perempuannyo, tetapi ketika di bujuk jadi mau. Tetapi si lakilaki akan membayar denda juga untuk istri pertama. Si laki-laki membayar denda ke perempuan, ke istri pertama. Istri kedua itu akan membayar denda juga, setelah denda itu dibayar barulah mereka boleh menikah. (DK, Jambi, 3 Agustus 2018)

"Sebenarnyo dak boleh itutu tapi dulu pernah terjadi di nenek puyang kami. Beristiri duo, tigo tapi itu harus di dendo besak. Misalnyo istri pertamo ado dendo 60 lembar kain terus bayar adatnyo. Intinyo kalo nak beistri banyak itukan berarti di madu nah lanangnyo harus adil samo semua istrinyo. Kalau minta izin rebut la dengan istri pertamo. Kalau la tejadi barula rapat itung berapo dendonyo trus kek mano bini pertamo apo cerai atau dimadu" (M, Sungai Terab 29 Juli 2018)

"Itu dakado larangan, paling ado adatnyo nak ngasih-ngasih itu tergantung hakimnyo" ( $\mathrm{T}$, Sungai Terab, 29 Juli 2018)

\section{Pola Konsumsi Suku Anak Dalam}

Makanan yang dikonsumsi oleh Suku Anak Dalam atau orang rimba biasanya bersumber dari yang ditemukan di hutan. Akan tetapi ada beberapa hewan yang tidak boleh dimakan (haram) dikarenakan ada perjanjian antar pihak tertentu. Semua binatang atau hewan peliharaan merupakan larangan bagi orang rimba untuk dimakan seperti ayam, kerbau, sapi atau kambing. Berikut cuplikan dari wawancara tersebut :

"Dulu tu sejarahnya, ada dua orang rimba bersaudara yang pisah, satu kehutan satunya lagi ke laut, kemudian mereka bersumpah jangan makan makanan kami. Jadi makanan mereka bukan yang dimakan orang luar. Artinya makanan kami ini dan makanan kalian itu, kita dak boleh makan makanan yang sama, ibaratnyo kalo ke darat diterkam harimau kelaut di terkam buayo. Ayam kerbau juga ga boleh dimakan, kalo rusa kancil boleh asal ga dipelihara" (DK, Jambi, 3 Agustus 2018)

"Dari nenek puyang kami semua ternak di dusun itu haram untuk orang rimbo. Orang dusun samo orang rimbo tu samo satu keturunan. Tapi orang dusun yang 
lari kerimbo ado sumpahnyo kek itu jugo orang rimbo lari ke dusun ado sumpahnyo. Jadi dulu tu sumpahnyo bebagi kek ayam kerbau ternak-ternak orang dusun haram hukumnyo untuk orang rimbo. Kayak ular, biawak itu haram bagi orang dusun. Ado pernah terjadi orang rimbo nak makan samo kayak orang dusun na dio (bujang-bujang) la kepengen nak makan macam orang dusun jadi la pegila ke dusun." (M, Sungai Terab 29 Juli 2018)

“... Jadi dulu kato bapak sayo ado sumpah dulu. Antara orang dusun dengan rimbo. Perjajian tentang di bagi lauk-lauk yang didusun dak boleh orang rimbo makannyo kek itu jugo orang rimbo $d k$ biso makan dengan orang dusun" (T, Sungai Terab, 29 Juli 2018)

\section{Status Gizi Balita}

iBerikut ini ditampilkan status gizi balita orang Rimba menurut TB/U (stunting) dan $\mathrm{BB} / \mathrm{U}$ (underweight) sebagai berikut :

Tabel 1. Status Gizi Balita Orang Rimba Menurut TB/U (Stunting)

\begin{tabular}{ccc}
\hline TB/U & $\mathrm{n}$ & $\%$ \\
\hline Sangat pendek & 2 & 8,7 \\
Pendek & 3 & 13,0 \\
Normal & 12 & 52,2 \\
Tinggi & 6 & 26,1 \\
Jumlah & 23 & 100,0 \\
\hline
\end{tabular}

Pada tabel diatas terlihat bahwa balita yang mengalami stunting mencapai $21,7 \%(8,7 \%$ pada status sangat pendek dan $13 \%$ pendek). Sedangkan balita dengan status gizi buruk mencapai $12 \%$ dan status gizi kurang juga $12 \%$, terlihat pada tabel berikut ini :

Tabel 2. Status Gizi Balita Orang Rimba Menurut BB/U

\begin{tabular}{lrr}
\hline BB/U & $\mathrm{n}$ & \multicolumn{1}{c}{$\%$} \\
\hline Gizi buruk & 3 & 12,0 \\
Gizi kurang & 3 & 12,0 \\
Gizi Baik & 18 & 72,0 \\
Gizi Lebih & 1 & 4,0 \\
Jumlah & 25 & 100,0 \\
\hline
\end{tabular}

\section{PEMBAHASAN}

Pola Perkawinan

Seseorang yang mempunyai hubungan darah akan lebih mungkin memberikan gen yang sama dibandingkan dengan orang - orang yang tidak mempunyai hubungan darah. Apabila seorang heterozigot untuk gen resesif menikahi saudara sepupunya, maka kemungkinannya adalah 1/8 bahwa saudara sepupunya tadi juga membawa gen yang sama. Misalkan angka 1 dalam 10.000 seperti frekuensi albinisme pada populasi umum sehingga kira - kira 1 dari 50 orang tentunya adalah heterozigot untuk gen yang membawa kelainan tersebut. Kemungkinan seseorang adalah heterozigot adalah sebesar 1/50, dan apabila ia menikah secara acak dengan orang yang tidak ada hubungan kerabat, maka kemungkinan pasangannya juga heterozigot adalah 1/50. Frekuensi 
perkawinan antara heterozigot yang demikian $1 / 50 \times 1 / 50=1 / 2500,1$ dari 2500 perkawinan akan mempunyai anak albino, seperti yang diharapkan bahwa diantara anak - anak adalah 1 berbanding 4, hal ini sesuai dengan frekuensi albinisme dalam populasi, yaitu 1 dalam 10.000 orang, kemungkinan seseorang heterozigot adalah 1/50, akan tetapi apabila seorang pria menikah dengan saudara sepupunya (first cousin) maka kemungkinan istrinya heterozigot adalah $1 / 8$ dan memberikan $1 / 50 \times 1 / 8=1 / 400$, sehingga satu diantara 400 perkawinan antara sepupu akan mempunyai anak albino ${ }^{4}$.

Seorang keturunan dari hasil perkawinan sedarah (inbreeding) akan memiliki keragaman genetik yang sangat minim dalam DNA-nya karena DNA turunan dari ayah dan ibunya adalah mirip, kurangnya variasi dalam DNA dapat berdampak buruk bagi kesehatan, hal ini bisa menyebabkan penyakit genetik langka yaitu albinisme, fibrosis sistik, hemofillia dan gangguan mental (Fenilketouria). Efek lain dari perkawinan sedarah (inbreeding) yaitu peningkatan infertelitas pada orang tua dan anaknya, cacat lahir seperti asimetri wajah, bibir sumbing, dan juga kekerdilan tubuh saat dewasa, gangguan jantung, kanker, BBLR, tingkat pertumbuhan lambat, dan kematian neonatal. Perkawinan sedarah berpotensi tinggi menghasilkan keturunan yang secara biologis lemah baik fisik ataupun mental (cacat) atau bahkan letal (mematikan). Kelainan fisik anak akibat dari perkawinan sedarah antara lain adalah rahang bawah lebih panjang, tengkorak memanjang dibagian belakang, jari-jari menyatu, hemophilia, mikrosefali, bibir sumbing, kaki pekuk, albinisme, tubuh mini, ketidaksuburan, scoliosis, gangguan sistem kekebalan tubuh, dan kriptorkrismus ${ }^{5}$.

Kelainan fisik anak akibat dari perkawinan sedarah salah satunya yaitu tubuh mini, anak - anak hasil dari perkawinan sedarah memiliki masalah dengan ketidaksuburan dan akhirnya mereka melihat adanya penyakit Ellis-Van Creveld, penyakit ini terkait dengan dwarfisme (cebol), serta stunting. Dwarfisme adalah suatu kondisi kelainan yang ditandai dengan tinggi tubuh yang pendek akibat kelainan medis atau genetik. Seorang manusia dewasa dikatakan mengalami dwarfisme bila tinggi badannya $147 \mathrm{~cm}$ atau lebih pendek. Kondisi ini lebih sering disebut dengan perawakan tubuh yang pendek dibandingkan penyebutan dwarfisme ${ }^{6}$.

\section{Pola Konsumsi dan Gambaran Status}

\section{Gizi Balita}

Berdasarkan model penyebab underweight yang dikembangkan UNICEF, banyak faktor yang menyebabkan underweight yang saling terkait baik secara langsung dipengaruhi oleh penyakit infeksi dan tidak cukupnya asupan gizi secara kuantitas dan kualitas, sedangkan secara tidak langsung 
underweight dipengaruhi oleh jangkauan dan kualitas pelayanan kesehatan, pola asuh anak yang kurang memadai, kurang baiknya kondisi sanitasi lingkungan serta rendahnya ketahanan pangan di tingkat rumah tangga ${ }^{7}$.

Kasus gizi buruk di Provinsi Jambi banyak disebabkan kemiskinan dan rendahnya pengetahuan ibu mengenai makanan bergizi. Kemiskinan keluarga membuat asupan makanan bergizi untuk anak-anak berkurang, kemudian kurangnya pengetahuan ibu mengenai makanan bergizi membuat mereka kurang memperhatikan kualitas makanan yang diberikan kepana anak-anak dan balita. Perubahan sosial pada Komunitas Adat Terpencil (KAT) atau dikenal dengan Suku Anak Dalam (SAD) atau Orang Rimba, perubahan yang dimaksud adalah terjadi perubahan pola kehidupan yang sebelumnya nomaden kini mereka telah memiliki hunian tetap. Kemiskinan semakin menjerat Orang rimba karena berkurangnya lahan dan sumber penghidupan mereka seperti meramu, berburu dan memanen hasil hutan. Hal ini dikarenakan banyaknya perubahan lahan hutan menjadi perkebunan kelapa sawit dan hutan tanaman industry (HTI) di Provinsi Jambi ${ }^{8}$. Pada tahun 2012, detik.com memberitakan bahwa akibat penjarahan hutan yang semakin luas mengakibatkan banyaknya Orang Rimba yang mengalami kematian akibat kekurangan pangan dan gizi, anak-anak Orang Rimba di Kabupaten Batanghari Provinsi Jambi kekurangan gizi yang ditandai dengan badan yang kurus, perutnya membuncit, tulang rusuknya menonjol dan matanya pun cekung ${ }^{9}$.

Penurunan masalah gizi terutama pengurangan balita underweight bergantung pada banyak faktor, dukungan sumber daya serta peningkatan kualitas manajemen teknis dan operasional. Kegiatan-kegiatan yang telah dilaksanakan di provinsi Jambi tersebut masih sangat terbatas dan belum mencakup pelaksanaan kegiatan teknis dan operasional yang menyentuh pada kegiatan revitalisasi posyandu sebagai upaya yang berbasis masyarakat dimana upaya kewaspadaan menurunnya keadaan gizi anak balita dapat dilaksanakan sendiri oleh masyarakat di Posyandu ${ }^{10}$.

Sebagaimana telah dikemukakan bahwa, hal yang dapat dilakukan dalam upaya menangkap anak-anak yang normalkurus, adalah dengan meningkatkan kegiatan surveilans gizi secara aktif, sehingga dapat segera dilakukan intervensi yang tepat. Tetapi bagi anak balita dengan tinggi badan pendek-normal harus dikurangi yaitu dengan melakukan upaya pencegahan dengan program seribu hari pertama kehidupan yang hasilnya mendatang. 


\section{KESIMPULAN DAN SARAN}

Dari uraian tersebut, dapat disimpulkan bahwa $21,7 \%$ balita pendek dan $24 \%$ balita gizi kurang pada Orang Rimba di Kabupaten Batanghari Jambi. Pola perkawinan kebanyakan dilakukan diantara keluarga atau memiliki hubungan kekerabatan. Usia rata-rata pernikahan adalah 11-14 tahun. Pola konsumsi tinggi lemak, rendah sayur dan buah serta asupan energi bersumber dari ubi dan beras. Adanya norma dan adat yang dijunjung tinggi oleh SAD bahwa wanita tidak boleh berkontak dengan orang luar, bahkan tidak diperkenankan mengambil photo atau gambar apapun dengan ibu atau wanita mereka, maka Tim peneliti tidak mendapatkan secara utuh status gizi, seharusnya didapatkan ketika kita mewawancarai langsung ibu atau wanita dari suku anak dalam tersebut. Proses pengumpulan data juga harus dilakukan berkali-kali mendatangi kelompok dan Tumenggung dengan fasilitasi dari WARSI yang berada dan tinggal Bersama mereka. Hingga saat ini, Tim Peneliti masih harus melakukan pengumpulan data di Desa Hajran dan Jelutih karena jumlah balita yang sangat sedikit dan tidak sesuai dengan jumlah sampel minimal pada tanggal 16 September 2018. .Beberapa rencana yang telah dituliskan di Proposal penelitian harus disesuaikan dengan kondisi lapangan.

Saran yang dapat disampaikan adalah perlunya pembinaan secara berkesinambungan dari Pemerintah khususnya Instansi terkait yaitu Dinas Kesehatan Kabupaten Batanghari dan Dinas Kesehatan Provinsi Jambi melalui Puskesmas dengan menempatkan lebih banyak lagi petugas kesehatan di lokasi Orang Rimba banyak ditemukan diantaranya melalui program Nusantara Sehat, sehingga aksesibilitas terhadap layanan kesehatan utamanya upaya promotif dan preventif dapat diberikan secara lebih paripurna dan berkelanjutan.

\section{UCAPAN TERIMA KASIH}

Ucapan terima kasih kepada Dekan FKM dan LPPM atas pendanaan penelitian ini, Lembaga Swadaya Masyarakat KKI WARSI dan Dinas Kesehatan Kabupaten Batanghari beserta jajarannya yang telah mendukung penelitian ini. Ucapan terima kasih juga disampaikan untuk Kepala Desa Sungai Terap dan Desa Hajran, Tumenggung beserta Waris yang telah memfasilitasi kegiatan penelitian ini.

\section{DAFTAR PUSTAKA}

1. WHO. (2017). Joint Child Malnutrition Estimates 2017 (UNICEF-WHO-WB). http://apps.who.int/gho/data/node.wra pper.nutrition-2016?lang=en. 
Published 2017. Accessed March 11, 2019.

2. Riskesdas. (2013). Riset Kesehatan Dasar (RISKESDAS) 2013. Lap Nas 2013. 2013:1-384. doi:1 Desember 2013.

3. BPS, \& Unicef. (2016). Kemajuan Yang Tertunda: Analisis Data Perkawinan Usia Anak Di Indonesia. Jakarta

4. Pai AC. (2006). Dasar-Dasar Genetika: Ilmu Untuk Masyarakat. Jakarta : Erlangga.

5. Fitriadi Y. (2014). Pengaruh Penyuluhan Tentang Palsi Serebral Terhadap Pengetahuan Masyarakat Umum. 2014.

6. Baikoussis NG, Argiriou M, Argiriou O, \& Dedeilias P. (2016). Perceval S Aortic Valve Implantation in an Achondroplastic Dwarf. 2016:166-168. doi:10.4103/0971-9784.173041.
7. Fitriani F, Febry F, \& Mutahar R. (2009). Gambaran Penyebab Kesulitan Makan Pada Anak Prasekolah Usia 3-5 Tahun Di Perumahan Top Amin Mulya Jakabaring Palembang Tahun 2009. 2009.

8. Suyanto, \& Mujiyadi B. (2015). Pemberdayaan Komunitas Adat Terpencil Melalui Pelayanan Terpadu Di Rote Ndao, Provinsi Nusa Tenggara Timur. 2015:15-36.

9. Detik. (2012). Hutan Terus Dijarah, Suku Terasing Di Jambi Kekurangan Gizi. https://news.detik.com/berita/d1867976/hutan-terus-dijarah-sukuterasing-di-jambi-kekurangan-gizi. Published 2012.

10. Azwar A. (2004). Kecenderungan Masalah Gizi Dan Tantangan Di Masa Datang. www.gizi.net. Published 2004. Accessed November 8, 2018. 